\title{
Characterization of Thiobacillus caldus sp. nov., a moderately thermophilic acidophile
}

\author{
Kevin B. Hallberg and E. Börje Lindström† \\ Author for correspondence: E. Börje Lindström. Tel: +46901767 50. Fax: +46 901126 30. e-mail: \\ GRPBL@comvax.umu.se
}

Department of Applied Cell and Molecular Biology, University of Umeå, S-901 87 Umeå, Sweden

\begin{abstract}
Two isolates of a novel, moderately thermophilic Thiobacillus species have been studied. The isolates, $\mathrm{KU}$ and BC13, are Gram-negative, motile bacteria having a pH optimum for growth of 2-2.5 and an optimum growth temperature of $45^{\circ} \mathrm{C}$. Both isolates are capable of chemolithotrophic growth on reduced sulfur substrates. They can also use molecular hydrogen as an electron donor. These two isolates can grow mixotrophically with sulfur or tetrathionate and yeast extract or glucose. The $G+C$ content is $63.1-63.9 \mathrm{~mol} \%$ and the isolates exhibit no significant DNA homology to any other Thiobacillus species. Strains KU and BC13 both contain ubiquinone Q-8. 16S rRNA analysis indicates that these strains belong to a group of bacteria which includes other chemolithotrophic sulfur oxidizers such as $T$. ferrooxidans and $T$. thiooxidans. These characteristics distinguish KU and BC13 from any other species described previously and they thus represent the first acidophilic, thermophilic Thiobacillus species, named $T$. caldus sp. nov., to be described. The type strain, referred to as strain KU in this paper, has been deposited in the Deutsche Sammlung von Mikroorganismen, Braunschweig, FRG, with the accession number DSM 8584.
\end{abstract}

Keywords: Thiobacillus caldus sp. nov., sulfur-oxidizer, moderate thermophile, acidophile, chemolithotroph

\section{INTRODUCTION}

Bacteria belonging to the genus Thiobacillus are able to oxidize reduced sulfur compounds. Other substrates for these bacteria include ferrous iron (Ingledew, 1982), molecular hydrogen (Drobner et al., 1990) and formate (Pronk et al., 1991), in addition to various organic compounds and sulfide minerals. The ability to oxidize sulfidic ores, and subsequently solubilize metals, makes them useful in the industrial application of leaching metals from the ores or for the enhanced recovery of precious metals.

One of the practical applications of mineral biotechnology is the enhanced recovery of gold from pyrite- and arsenopyrite-containing ores (Lindström et al., 1992). The

†Present address: Department of Microbiology, University of Umeå, S-901 87 Umeå, Sweden.

Abbreviation: RDP, Ribosomal Database Project.

The EMBL accession number for the sequence reported in this paper is Z29975. use of bioleaching in gold recovery is generally limited to stirred tank reactors where reaction conditions can be controlled (Lawrence, 1990). Leaching reactions are exothermic and thus bioleaching at elevated temperatures offers several advantages. For example, the leaching rates are faster and the need for cooling is reduced.

Studies with the extremely thermophilic archaeon Sulfolobus have shown that high temperature leaching (up to $70{ }^{\circ} \mathrm{C}$ ) is possible yielding high oxidation rates (Lindström et al., 1993). Concern for the sensitivity of Sulfolobus to high pulp densities of mineral has been raised (Norris \& Barr, 1988). Other, moderately thermophilic, Gram-positive and Gram-negative iron- and sulfuroxidizers have been isolated (Ghauri \& Johnson, 1991; Marsh \& Norris, 1983) which have potential use in bioleaching. In addition to these isolates, there has been a report of the isolation of sulfur-oxidizing bacteria, claimed to be Thiobacillus thiooxidans, from acidic soil around hot springs with growth at up to $55^{\circ} \mathrm{C}$ (Fliermans \& Brock, 1972).

In this paper, we characterize the properties of two moderately thermophilic, sulfur-oxidizing acidophiles 
isolated from coal spoils. We propose that these bacteria should be recognized as Thiobacillus caldus sp. nov., the first acidophilic species of thermophilic thiobacilli to be described.

\section{METHODS}

Bacteria and growth conditions. The two strains characterized in this study were Thiobacillus BC13 and KU. Strain BC13 was from Dr Paul Norris, University of Warwick, Coventry, UK, and a stock culture was made by streaking out the culture on solid medium. A single colony was used to inoculate liquid medium. Strain KU was isolated from a tetrathionatemaintained culture derived from a Kingsbury coal spoil enrichment culture (Marsh \& Norris, 1983) by streaking a single colony three consecutive times on solid medium. The final single colony was inoculated into liquid medium. Both liquid cultures in mid-exponential phase were concentrated 50 -fold in mineral salts medium, made to $7 \%(\mathrm{v} / \mathrm{v})$ dimethyl sulfoxide and maintained as stock cultures at $-80^{\circ} \mathrm{C}$. These stock cultures have retained viability for over 3 years. Strain KU has been deposited in the Deutsche Sammlung von Mikroorganismen, Braunschweig, FRG, with the accession number DSM 8584.

Bacteria were grown in a medium consisting of the basal salts $\left(\mathrm{g} \mathrm{l}^{-1}\right)\left(\mathrm{NH}_{4}\right)_{2} \mathrm{SO}_{4}(3 \cdot 0), \mathrm{Na}_{2} \mathrm{SO}_{4} \cdot 10 \mathrm{H}_{2} \mathrm{O}(3 \cdot 2), \mathrm{KCl}(0 \cdot 1)$, $\mathrm{K}_{2} \mathrm{HPO}_{4}(0 \cdot 05), \mathrm{MgSO}_{4} \cdot 7 \mathrm{H}_{2} \mathrm{O}(0 \cdot 5)$ and $\mathrm{Ca}\left(\mathrm{NO}_{3}\right)_{2}(0 \cdot 01)$, and the following trace elements $\left(\mathrm{mg} \mathrm{l}^{-1}\right)$ : $\mathrm{FeCl}_{3} \cdot 6 \mathrm{H}_{2} \mathrm{O}(11 \cdot 0)$, $\mathrm{CuSO}_{4} \cdot 5 \mathrm{H}_{2} \mathrm{O}(0 \cdot 5), \quad \mathrm{HBO}_{3}(2 \cdot 0), \quad \mathrm{MnSO}_{4} \cdot \mathrm{H}_{2} \mathrm{O}(2 \cdot 0)$, $\mathrm{Na}_{2} \mathrm{MoO}_{4} \cdot 2 \mathrm{H}_{2} \mathrm{O}(0 \cdot 8), \mathrm{CoCl}_{2} \cdot 6 \mathrm{H}_{2} \mathrm{O}(0 \cdot 6)$ and $\mathrm{ZnSO}_{4} \cdot 7 \mathrm{H}_{2} \mathrm{O}$ $(0.9)$. The basal salts were adjusted to $\mathrm{pH} 2.5$ with $\mathrm{H}_{2} \mathrm{SO}_{4}$ and autoclaved before the filter-sterilized trace elements were added. The growth temperature was generally $45 \pm 1{ }^{\circ} \mathrm{C}$ and the growth medium was sparged with $\mathrm{CO}_{2}$-entiched air $(2 \%, \mathrm{v} / \mathrm{v})$. Media were solidified with $1.5 \%(\mathrm{w} / \mathrm{v})$ Phytagel (Sigma) essentially as previously described (Lindström \& Sehlin, 1989), with the exception that the $\mathrm{pH}$ of the double strength mineral salts solution was adjusted to 1.75 to ensure a final $\mathrm{pH}$ of 2.5 in the solid media.

Growth rates were determined in 1.51 reactors with constant $\mathrm{pH}$ maintenance using $\mathrm{NaOH}$. The effect of temperature on growth rate was determined at the indicated temperatures at $\mathrm{pH} 2.0$. The determination of optimal $\mathrm{pH}$ for growth was performed at $45^{\circ} \mathrm{C}$. The growth rates were calculated from the exponential increase in optical density measured at $440 \mathrm{~nm}$.

Substrate utilization. The main growth substrate used in this study was tetrathionate. In addition, the following sulfurcontaining substrates were tested: $0.5 \%$ flowers of sulfur; thiosulfate, added in pulses of $0.25 \mathrm{mM} \mathrm{h}^{-1}$ to minimize abiotic degradation in the acidic medium; and sulfide, as a gradient in $0.025 \%$ Phytagel over a $1 \%(\mathrm{w} / \mathrm{v})$ sulfide-containing Phytagel base (Drobner et al., 1992). Pyrite $\left(\mathrm{FeS}_{2}\right)$ was also tested as a growth substrate as a $1 \%(\mathrm{w} / \mathrm{v})$ suspension in mineral salts medium with an initial $\mathrm{pH}$ of 1.8 .

Growth with $50 \mathrm{mM} \mathrm{FeSO}_{4}$ was tested in mineral salts medium at $\mathrm{pH} 1.7$, with and without $0.05 \%$ yeast extract or $2.5 \mathrm{mM}$ glucose. Heterotrophic growth was tested in basal salts amended only with $0.05 \%$ yeast extract, $0.05 \%$ Casamino acids, or $2.5 \mathrm{mM}$ glucose. Oxidation of molecular hydrogen and formic acid was tested as previously described for $T$. ferrooxidans (Drobner et al., 1990; Pronk et al., 1991).

Transmission electron microscopy. Bacteria were fixed in $2.5 \%$ $(\mathrm{w} / \mathrm{v})$ glutaraldehyde and $1 \%(\mathrm{w} / \mathrm{v})$ osmium tetroxide for $1 \mathrm{~h}$ each before dehydration in a graded series of ethanol. After embedding, thin sections were post-stained with uranyl acetate and lead citrate. Flagella were observed by drying bacteria onto carbon-coated grids, washing with water and staining with uranyl acetate.

Chemotaxonomy. Ubiquinones were extracted from $500 \mathrm{mg}$ wet weight of bacteria as described by DiSpirito et al. (1983) and were identified by UV spectroscopy following separation by HPLC. The standards used were Q-7, Q-9 and Q-10 (Sigma) with ubiquinones isolated from Salmonella typhimurium as the Q8 standard. LPS was determined by polyacrylamide gel electrophoresis of untreated or proteinase $\mathrm{K}$-treated whole cell lysates followed by LPS-specific silver staining (Hitchcock \& Brown, 1983).

DNA analysis. Chromosomal DNA was extracted from strains $\mathrm{KU}$ and $\mathrm{BC} 13$ using a proteinase $\mathrm{K}-\mathrm{SDS}$ procedure (Wilson, 1987) and subsequently purified on $\mathrm{CsCl}$ gradients. The $\mathrm{G}+\mathrm{C}$ content was determined by melting point analysis in $0.1 \times \mathrm{SSC}$ $(1 \times \mathrm{SSC}$ is $0.15 \mathrm{M} \mathrm{NaCl}, 0.015 \mathrm{M}$ trisodium citrate, $\mathrm{pH} 7 \cdot 0)$ (Marmur \& Doty, 1962) with calf thymus DNA (42 mol\% $\mathrm{G}+\mathrm{C}$ ) as standard. DNA-DNA homology was determined by filter hybridization (König, 1984). The indicated DNA was labelled with $\left[\alpha_{-}^{32} \mathrm{P}\right] \mathrm{dCTP}$ by nick translation. DNA from other organisms used in the homology experiments was kindly provided by Dr Harald Huber, University of Regensburg, FRG.

$16 S$ rRNA gene sequencing. $16 \mathrm{~S}$ rDNA was amplified by PCR using a forward primer complementary to positions 8-27 of Eschericbia coli $16 \mathrm{~S} \mathrm{rRNA}$ and a reverse primer complementing positions 1510-1492 (Lane, 1991). The amplification reaction (50 $\mu$ l final volume) consisted of the following: $0 \cdot 25 \mu \mathrm{g}$ purified chromosomal DNA, $5 \mu \mathrm{l}$ of $10 \times$ reaction buffer $(200 \mathrm{mM}$ Tris/ $\mathrm{HCl}, \mathrm{pH} \mathrm{8.3,} 25 \mathrm{mM} \mathrm{MgCl}_{2}, 500 \mathrm{mM} \mathrm{KCl}, 0.5 \%$ Tween 20 and $1 \mathrm{mg}$ gelatin $\mathrm{ml}^{-1}$ ), $200 \mu \mathrm{M}$ of each dNTP, $50 \mathrm{ng}$ of each primer and $2.5 \mathrm{U}$ of $\mathrm{Taq}$ polymerase. The reaction mixture was incubated in a thermal cycler at $95^{\circ} \mathrm{C}$ for $3 \mathrm{~min}$ before 25 cycles as follows: $95^{\circ} \mathrm{C}$ for $30 \mathrm{~s}, 50^{\circ} \mathrm{C}$ for $30 \mathrm{~s}$ and $72{ }^{\circ} \mathrm{C}$ for $1 \mathrm{~min}$ ( $5 \mathrm{~min}$ on the last cycle). Following amplification, the product was cloned into the p T7Blue T-vector (Novagen) and sequenced by the dideoxy chain termination method (Sanger et al., 1977) with internal primers of the 16S rRNA molecule (Lane, 1991).

The sequence obtained was compared to other sequences in the Ribosomal Database Project (RDP) using the similarity rank program (Larsen et al., 1993). 16S rRNA sequences of various bacteria were obtained from the RDP and the sequence from strain $\mathrm{KU}$ was aligned with them. This alignment was used to construct a distance matrix (Jukes \& Cantor, 1969) and the distance matrix was used to construct a phylogenetic tree by the neighbour joining method (Saitou \& Nei, 1987). Both algorithms were provided in PHYLIP version $3.5 \mathrm{c}$ obtained from Dr Joseph Felsenstein, University of Washington, USA.

\section{RESULTS}

\section{Morphology}

Phase contrast microscopy revealed that the two isolates are short, rod-shaped organisms, frequently observed as pairs. Strain BC13 measured approximately $1.2 \mu \mathrm{m} \times$ $0.7 \mu \mathrm{m}$ and strain $\mathrm{KU}$ approximately $1.8 \mu \mathrm{m} \times 0.8 \mu \mathrm{m}$. Both strains showed a negative Gram reaction and both had a typical Gram-negative cell wall, as shown by transmission electron microscopy for KU (Fig. 1a). 
(a)
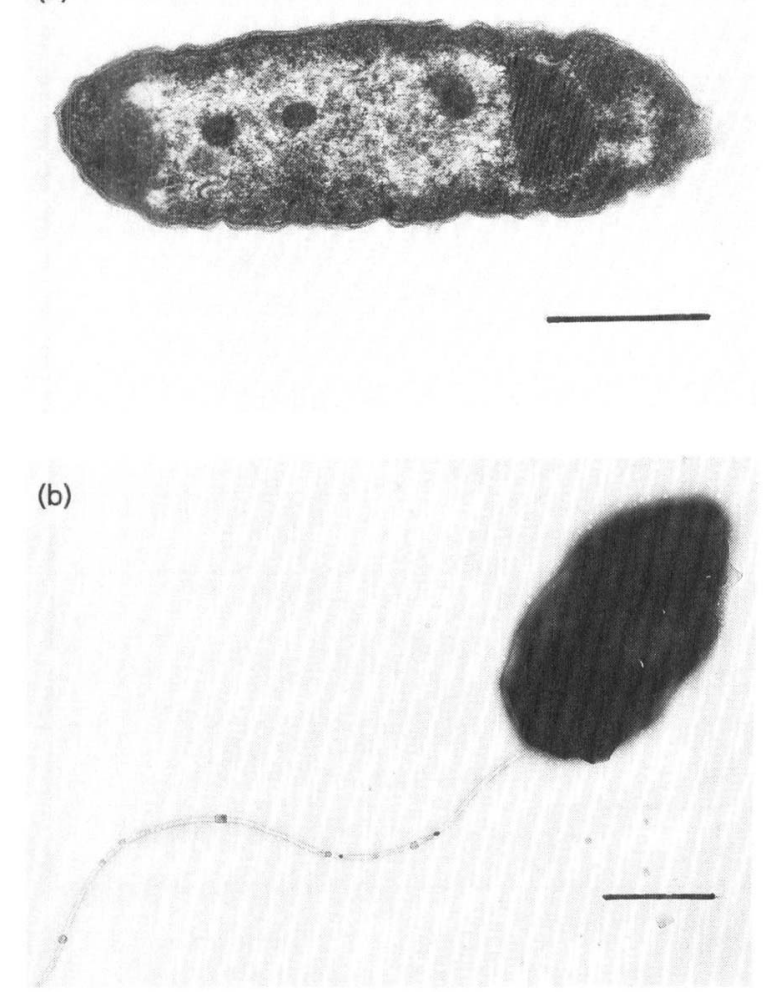

Fig. 1. Electron micrographs of Thiobacillus strain $\mathrm{KU}$ showing (a) a thin section and (b) negatively stained cells with a single, polar flagellum. Bars, $1 \mu \mathrm{m}$.

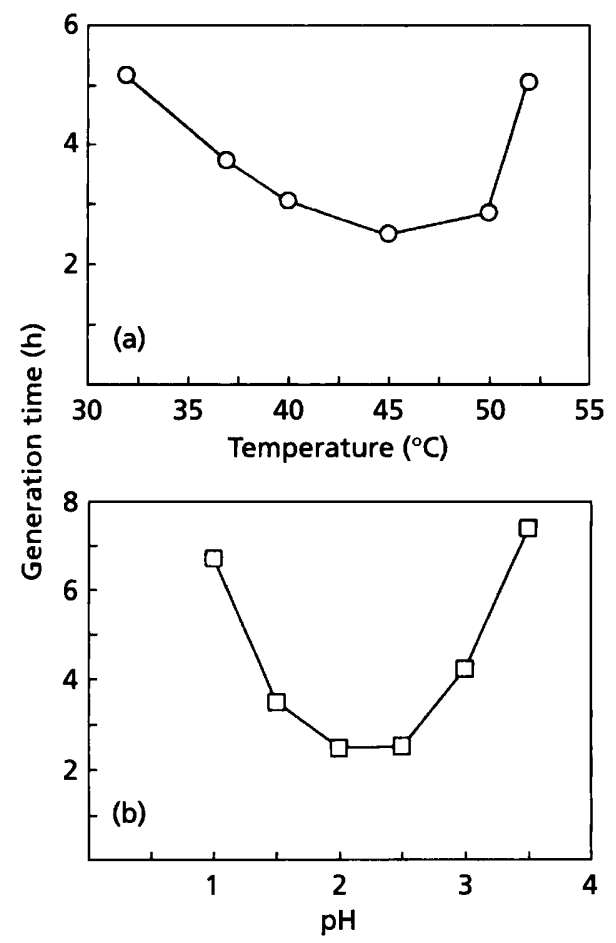

Fig. 2. Growth rate of Thiobacillus strain $\mathrm{KU}$ as a function of (a) temperature at $\mathrm{pH} 2.0$ and (b) $\mathrm{pH}$ at $45^{\circ} \mathrm{C}$.
Strains $\mathrm{BC} 13$ and $\mathrm{KU}$ are motile bacteria with one polar flagellum (Fig. 1b).

\section{Growth conditions}

The range of temperature for growth with tetrathionate as growth substrate at $\mathrm{pH} 2$ was determined for each of the two strains. Strain $\mathrm{KU}$ grew at $32 \pm 1{ }^{\circ} \mathrm{C}$, the lowest temperature tested (Fig. 2a). The highest temperature for growth was $52 \pm 1{ }^{\circ} \mathrm{C}$ with $45 \pm 1{ }^{\circ} \mathrm{C}$ being optimal (Fig. 2a). A similar temperature profile was obtained for strain BC13. No growth was observed at $55^{\circ} \mathrm{C}$ for either strain on tetrathionate, while growth of strain BC13 on sulfur at $55^{\circ} \mathrm{C}$ has been previously reported (Norris et al., 1986).

Strains $\mathrm{BC} 13$ and $\mathrm{KU}$ exhibited a broad $\mathrm{pH}$ range for growth in tetrathionate media at $45^{\circ} \mathrm{C}$. Growth at $\mathrm{pH} 4.0$ was slow, with a generation time of $45 \mathrm{~h}$. The growth rate of strain $\mathrm{KU}$ was reduced to $2.3 \mathrm{~h}$ at $\mathrm{pH} 2.0$ and 2.5 (Fig. 2b). At pH $1 \cdot 0$, strain $\mathrm{KU}$ had a growth rate of $6 \cdot 7 \mathrm{~h}$ (Fig. $2 \mathrm{~b}$ ), while at $\mathrm{pH} 0.5$ no growth was observed. At $\mathrm{pH} 1.0$ the cells grew in long filaments. As with temperature dependence, strain $\mathrm{BC} 13$ had nearly identical growth rates as strain $\mathrm{KU}$ at the various $\mathrm{pH}$ values.

\section{Metabolism}

Several potential growth substrates were tested with both isolates. Chemolithoautotrophic growth of the two strains occurred with sulfur, tetrathionate, and thiosulfate. Sulfate was produced as the end product. Both strains grew as a turbid ring in soft Phytagel when provided a gradient of sulfide. Growth of these bacteria was enhanced by supplementing the air used for sparging with $2 \%(\mathrm{v} / \mathrm{v}) \mathrm{CO}_{2}$.

Heterotrophic growth did not occur with $0.05 \%$ yeast extract or Casamino acids, nor with $2.5 \mathrm{mM}$ glucose as sole substrate. Growth occurred mixotrophically with tetrathionate and yeast extract or glucose and the final growth yields were higher than those of tetrathionategrown cultures. The utilization of glucose by sulfuroxidizing cultures of strain $\mathrm{BC} 13$ has been noted previously (Norris et al., 1986). These authors also reported that strain BC13 could not grow on glucose alone after transfer from sulfur plus glucose, which is also the case for strains $\mathrm{KU}$ and $\mathrm{BC} 13$ grown on tetrathionate plus glucose.

In addition to the sulfur compounds, both isolates were able to oxidize molecular hydrogen.

Growth was not observed with formic acid, ferrous iron, or ferrous iron plus $0.05 \%$ yeast extract, nor with the mineral pyrite.

\section{DNA base composition}

Chromosomal DNA was isolated from strains $\mathrm{KU}$ and $\mathrm{BC} 13$ and was analysed for base composition. The $\mathrm{G}+\mathrm{C}$ content for strain BC13 was $63.1 \mathrm{~mol} \%$ and for strain $\mathrm{KU}$ it was $63.9 \mathrm{~mol} \%$. The $\mathrm{G}+\mathrm{C}$ content of strain $\mathrm{BC} 13$ was previously determined to be $61.7 \mathrm{~mol} \%$ (Norris et al., 1986). 

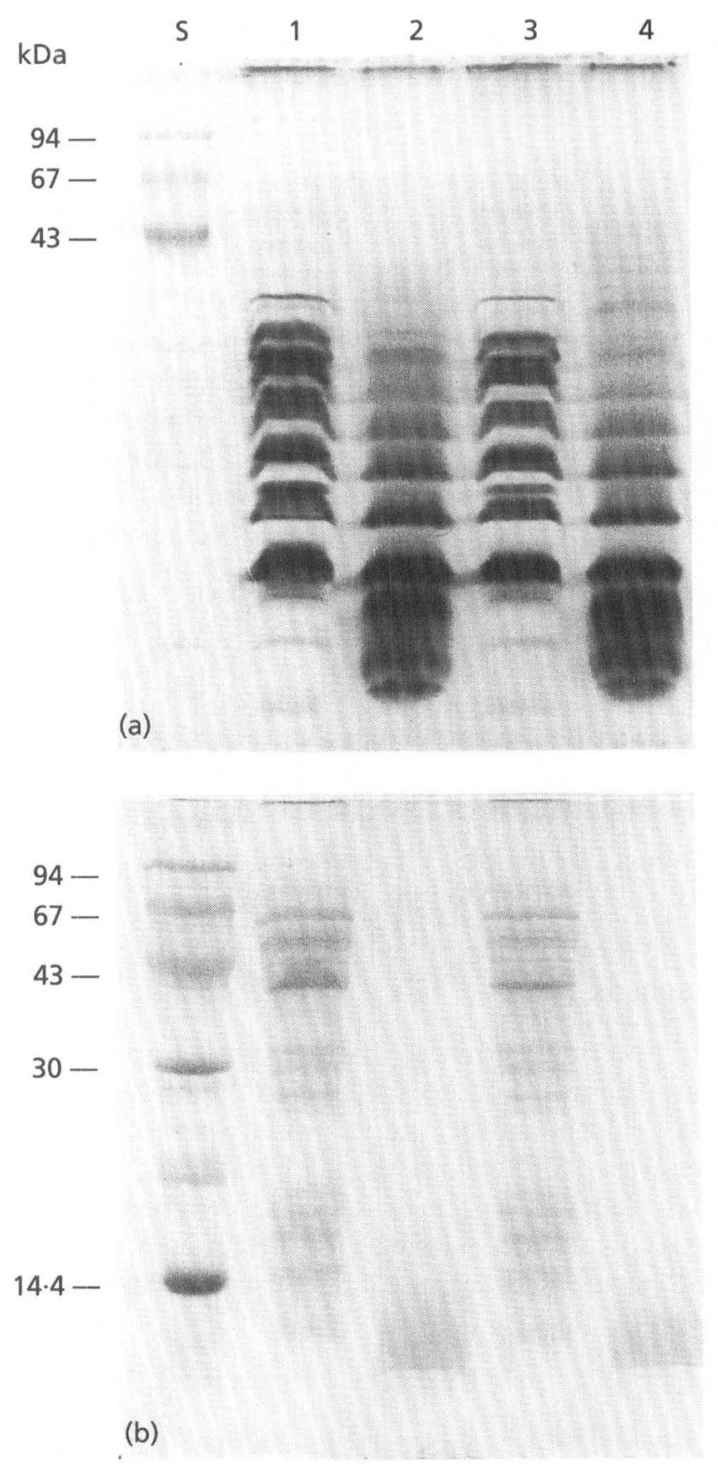

Fig. 3. PAGE analysis of whole cell lysates followed by staining with (a) silver for LPS or (b) Coomassie brilliant blue. Lanes: 1 and 3, untreated lysates of Thiobacillus strains $\mathrm{KU}$ and $\mathrm{BC} 13$, respectively; 2 and 4 , lysates of strains $\mathrm{KU}$ and $\mathrm{BC} 13$ treated with proteinase $\mathrm{K}$. Each gel was loaded with the same concentration of molecular mass standards (lane S) to indicate the specificity of the LPS staining.

\section{DNA hybridization studies}

DNA-DNA hybridization studies were performed with DNA from strains $\mathrm{KU}$ and $\mathrm{BC} 13$ as well as from Thiobacillus type strains. Strains KU and BC13 exhibited $100 \%$ homology with each other (Table 1). No homology was observed with other Thiobacillus strains.

\section{Chemotaxonomic markers}

Both strains KU and BC13 contained ubiquinone Q-8. An unidentified menaquinone was also observed in the quinone extracts. These isolates can thus be considered to be members of Thiobacillus group III (Katayama-Fujimura
Table 1. Percentage DNA-DNA homology of Thiobacillus strains $\mathrm{KU}$ and $\mathrm{BC} 13$ with Thiobacillus type strains

\begin{tabular}{|lcc|}
\hline Immobilized DNA & \multicolumn{2}{c|}{$\begin{array}{c}\text { 32P-Labelled } \\
\text { DNA (\%) }\end{array}$} \\
\cline { 2 - 3 } & $\begin{array}{c}\text { Strain } \\
\text { KU }\end{array}$ & $\begin{array}{c}\text { Strain } \\
\text { BC13 }\end{array}$ \\
& & \\
\hline Strain KU & 100 & 102 \\
Strain BC13 & 108 & 100 \\
T. ferrooxidans ATCC 23270* & $6 \cdot 4$ & $2 \cdot 2$ \\
T. thiooxidans ATCC 19377* & 12 & 16 \\
T. cuprinus DSM 5495* & 5 & 6 \\
T. thioparus DSM 505† & 20 & 16 \\
\hline
\end{tabular}

* Type strain.

† Type species.

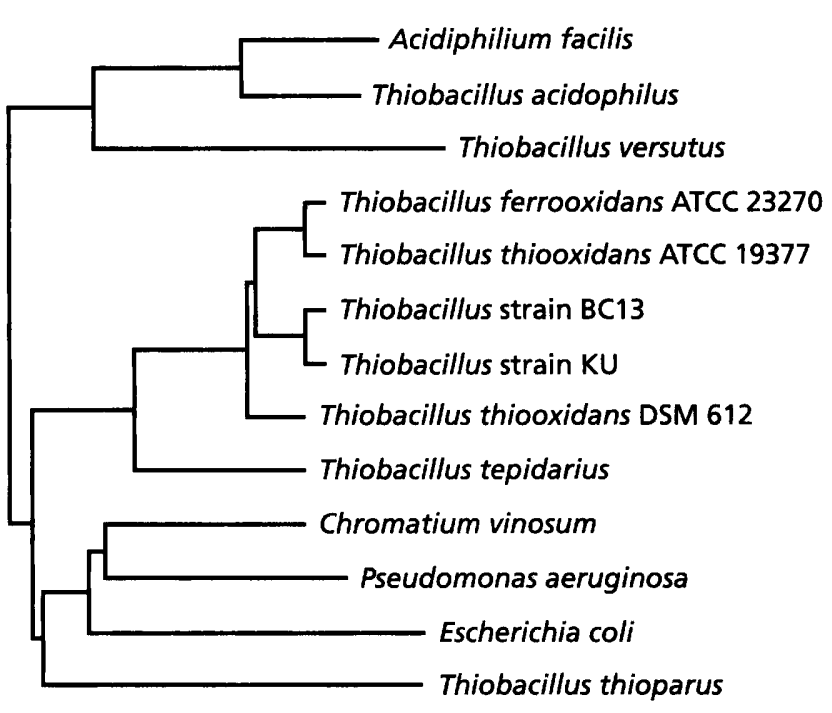

Fig. 4. Phylogenetic relationship of Thiobacillus strains $\mathrm{KU}$ and BC13 to other selected proteobacteria based on 16S IRNA sequences contained in the RDP. Branch lengths are proportional to the calculated evolutionary distances. The tree was rooted using Bacillus subtilis as an outgroup.

et al., 1982). The LPS, a marker of Gram-negative bacteria, of both isolates appeared to be similar (Fig. 3).

\section{S rRNA analysis}

A nearly complete sequence of the $16 \mathrm{~S}$ rRNA gene (1469 bp) was obtained from strain KU. The structure of the helices between bp 180 and 220 ( $E$. coli numbering) suggests that strain $\mathrm{KU}$ belongs to the $\beta / \gamma$ subdivision of proteobacteria (Woese, 1987). Comparison of the sequence with sequences in the RDP indicated a close phylogenetic relationship to other chemolithotrophic members of the genus Thiobacillus. The sequence had an identity of $99 \cdot 3 \%$ with the partial sequence of strain BC13 
(Lane et al., 1992). It must be pointed out here, as recently discussed by Goebel \& Stackebrandt (1994), that the strain designated by Lane et al. (1992) as LM2 is in fact BC13 and the strain called BC is LM2 (Dr Paul Norris, personal communication). The correct nomenclature is used in this paper.

Using an alignment of the sequences of the 16S rRNA from strain $\mathrm{KU}$ and other bacteria, a phylogenetic tree was constructed (Fig. 4). Within the cluster of bacteria related to strain $\mathrm{KU}$ are included both acidophiles and neutrophiles, including the moderately thermophilic, neutrophilic $T$. tepidarius. Strain BC13 exhibits a very close relationship to strain $\mathrm{KU}$, as would be expected.

\section{DISCUSSION}

Moderately thermophilic bacteria have been isolated from various habitats. The bacteria are usually differentiated by their optimal growth temperature of about $45^{\circ} \mathrm{C}-50{ }^{\circ} \mathrm{C}$, apparent lack of sulfate assimilation and spore formation (Norris, 1990). One group of isolates is related to Sulfobacillus thermosulfidooxidans (Karavaiko et al., 1990) and are usually Gram-positive or yield ambiguous Gram stain results. Three isolates, TH3, LM2 and ALV, have been shown by $16 \mathrm{~S}$ rRNA sequencing to belong to the Gram-positive division of the eubacteria (Lane et al., 1992).

The two moderately thermophilic bacteria described in this paper are rod-shaped, Gram-negative and can utilize reduced sulfur compounds as electron donors for growth. Based upon these characteristics, they belong to the genus Tbiobacillus. These bacteria, unlike other described acidophilic members of the genus, have an optimal growth temperature of $45^{\circ} \mathrm{C}$ and thus represent the first moderately thermophilic, acidophilic Thiobacillus species. Two thermophilic Tbiobacillus species, T. tepidarius (Wood \& Kelly, 1985) and 'T. aquaesulis' (Wood \& Kelly, 1988), have been previously described, but both are neutrophilic. Strains KU and BC13 did not show any DNA homology with other Thiobacillus type strains, including T. ferrooxidans, T. thiooxidans and T. thioparus. The two strains exhibit $100 \%$ homology between each other and therefore can be considered to be two isolates of the same species.

It has been reported previously that strain $\mathrm{BC} 13$ cannot grow by oxidation of pyrite in pure culture while it can grow when in mixed culture with the iron-oxidizing 'Leptospirillum ferrooxidans' (Norris, 1990). Using strainspecific antibodies raised against strain KU, it has recently been shown by slot immunobinding assay that these bacteria are significant constituents of a moderately thermophilic mixed culture used in pilot scale leaching studies (Amaro et al., 1994). Also, a group of moderately thermophilic, sulfur-oxidizing bacteria represented by strain C-SH12, were isolated from laboratory-scale continuous bioreactors operating at $40^{\circ} \mathrm{C}$ (Goebel \& Stackebrandt, 1994). By $16 \mathrm{~S}$ rDNA sequence analysis (Goebel \& Stackebrandt, 1994), these isolates were shown to be highly related to strain $\mathrm{BC} 13$, referred to as Thiobacillus BC. These data indicate that, although these bacteria cannot oxidize ores, they can be a significant part of bioleaching cultures in reactors which are operating at elevated temperatures.

\section{Description of Thiobacillus caldus}

The description of T. caldus (cal.dus L. M. adj., warm) given here is based upon the type strain DSM 8584, referred to in this paper as strain KU. Cells are short, motile, Gram-negative rods. T. caldus is capable of chemolithoautotrophic growth with thiosulfate, tetrathionate, sulfide, sulfur and molecular hydrogen. T. caldus can grow mixotrophically with tetrathionate and glucose or yeast extract. Growth does not occur with ferrous iron or sulfidic ores, with or without an organic amendment. Colonies formed on solid tetrathionate medium are small, circular, convex, smooth and transparent, with precipitated sulfur in the centre of the colony. Growth occurs from $32{ }^{\circ} \mathrm{C}$ to $52{ }^{\circ} \mathrm{C}$, the optimum temperature being $45^{\circ} \mathrm{C}$, and at $\mathrm{pH} 1 \cdot 0-3 \cdot 5,2 \cdot 0-2 \cdot 5$ being optimal. The DNA contains $63.9 \mathrm{~mol} \% \mathrm{G}+\mathrm{C}$. No significant DNA-DNA hybridization has been detected with other Thiobacillus type strains. The respiratory chain contains ubiquinone Q-8 and a menaquinone.

\section{ACKNOWLEDGEMENTS}

Siv Sääf is gratefully acknowledged for her technical assistance. We would also like to thank Dr Harald Huber for bench space at the University of Regensburg, many helpful suggestions and the DNA used in the homology experiments. This work was supported in part by grants from Nordic Industrial Fund, Swedish National Board for Technical and Industrial Development and Swedish Agency for Research Cooperation with Developing Countries. K. B.H. would like to thank FEMS for a Fellowship for Young Scientists.

\section{REFERENCES}

Amaro, A. M., Hallberg, K. B., Lindström, E. B. \& Jerez, C. A. (1994). An immunological assay for detection and enumeration of thermophilic biomining microorganisms. Appl Environ Microbiol 60, 3470-3473.

DiSpirito, A. A., Loh, H. T. \& Tuovinen, O. H. (1983). A novel method for the isolation of bacterial quinones and its application to appraise the ubiquinone composition of Thiobacillus ferrooxidans. Arch Microbiol 135, 77-80.

Drobner, E., Huber, H. \& Stetter, K. O. (1990). Thiobacillus ferrooxidans, a facultative hydrogen oxidizer. Appl Environ Microbiol 56, 2922-2923.

Drobner, E., Huber, H., Rachel, R. \& Stetter, K. O. (1992). Thiobacillus plumbophilus spec. nov., a novel galena and hydrogen oxidizer. Arch Microbiol 157, 213-217.

Fliermans, C. B. \& Brock, T. D. (1972). Ecology of sulfur-oxidizing bacteria in hot acid soils. J Bacteriol 111, 343-350.

Ghauri, M. A. \& Johnson, D. B. (1991). Physiological diversity amongst some moderately thermophilic iron-oxidising bacteria. FEMS Microbiol Ecol 85, 327-334.

Goebel, B. M. \& Stackebrandt, E. (1994). Cultural and phylogenetical analysis of mixed microbial populations found in natural and commercial bioleaching environments. Appl Environ Microbiol 60, 1614-1621. 
Hitchcock, P. J. \& Brown, T. M. (1983). Morphological heterogeneity among Salmonella lipopolysaccharides in silver-stained polyacrylamide gels. J Bacteriol 154, 269-277.

Ingledew, W. J. (1982). Thiobacillus ferrooxidans: the bioenergetics of an acidophilic chemolithotroph. Biocbim Biopbys Acta 683, 89-117.

Jukes, T. H. \& Cantor, C. R. (1969). Evolution of protein molecules. In Mammalian Protein Metabolism, pp. 21-132. Edited by H. N. Munro. New York: Academic Press.

Karavaiko, G. I., Bulygina, E. S., Tsaplina, I. A., Bogdanova, T. I. \& Chumakov, K. M. (1990). Sulfobacillus thermosulfidooxidans: a new lineage of bacterial evolution? FEBS Lett 261, 8-10.

Katayama-Fujimura, Y., Tsuzaki, N. \& Kuraishi, H. (1982). Ubiquinone, fatty acid and DNA base composition determination as a guide to the taxonomy of the genus Tbiobacillus. J Gen Microbiol 128, 1599-1611.

König, H. (1984). Isolation and characterization of Metbanobacterium uliginosum sp. nov. from a marshy soil. Can J Microbiol 30, 1477-1481.

Lane, D. J. (1991). 16S/23S rRNA sequencing. In Nucleic Acid Techniques in Bacterial Systematics, pp. 115-175. Edited by E. Stackebrandt \& M. Goodfellow. New York: Wiley.

Lane, D. J., Harrison, A. P., Jr, Stahl, D., Pace, B., Giovanni, S. J., Olsen, G. J. \& Pace, N. R. (1992). Evolutionary relationships among sulfur- and iron-oxidizing eubacteria. J Bacteriol 174, 269-278.

Larsen, N., Olsen, G. J., Maidak, B. L., McCaughey, M. J., Overbeek, R., Macke, T. J., Marsh, T. L. \& Woese, C. R. (1993). The ribosomal database project. Nucleic Acids Res 21(Supplement), 3021-3023.

Lawrence, R. W. (1990). Biotreatment of gold ores. In Microbial Mineral Recovery, pp. 127-148. Edited by H. L. Ehrlich \& C. L. Brierley. New York: McGraw-Hill.

Lindström, E. B. \& Sehlin, H. M. (1989). High efficiency plating of the thermophilic sulfur-dependent archaebacterium Sulfolobus acidocaldarius. Appl Environ Microbiol 55, 3020-3021.

Lindström, E. B., Gunneriusson, E. \& Tuovinen, O. H. (1992). Bacterial oxidation of refractory sulfide ores for gold recovery. Crit Rev Biotechnol 12, 133-155.

Lindström, E. B., Wold, S., Ketteneh-Wold, N. \& Sääf, S. (1993). Optimization of pyrite bioleaching using Sulfolobus acidocaldarius. Appl Microbiol Biotechnol 38, 702-707.
Marmur, J. \& Doty, P. (1962). Determination of base composition of deoxyribonucleic acid from its thermal denaturation temperature. $J$ Mol Biol 5, 109-118.

Marsh, R. M. \& Norris, P. R. (1983). The isolation of some thermophilic, autotrophic, iron- and sulfur-oxidizing bacteria. FEMS Microbiol Lett 17, 311-315.

Norris, P. R. (1990). Acidophilic bacteria and their activity in mineral sulfide oxidation. In Microbial Mineral Recovery, pp. 3-27. Edited by H. L. Ehrlich \& C. L. Brierley. New York: McGraw Hill.

Norris, P. R. \& Barr, D. W. (1988). Bacterial oxidation of pyrite in high temperature reactors. In Biobydrometallurgy, pp. 532-536. Edited by P. R. Norris \& D. P. Kelly. Kew, Surrey, UK: Science \& Technology Letters.

Norris, P. R., Marsh, R. M. \& Lindström, E. B. (1986). Growth of mesophilic and thermophilic acidophilic bacteria on sulfur and tetrathionate. Biotechnol Appl Biochem 8, 318-329.

Pronk, J. T., Meijer, W. M., Hazeu, W., van Dijken, J. P., Bos, P. \& Kuenen, J. G. (1991). Growth of Thiobacillus ferrooxidans on formic acid. Appl Environ Microbiol 57, 2057-2062.

Saitou, N. \& Nei, M. (1987). The neighbor-joining method: a new method for reconstructing phylogenetic trees. Mol Biol Evol 4, 406-425.

Sanger, F., Nicklen, S. \& Coulson, A. R. (1977). DNA sequencing with chain-terminating inhibitors. Proc Natl Acad Sci USA 74, 5463-5467.

Wilson, K. (1987). Preparation of genomic DNA from bacteria. In Current Protocols in Molecular Biology, pp. 2.4.1-2.5.4. Edited by F. M. Ausubel, R. Brent, R. E. Kingston, D. D. Moore, J. A. Seidman \& K. Struhl. New York: Green \& Wiley Interscience.

Woese, C. R. (1987). Bacterial evolution. Microbiol Rev 51, 221-271.

Wood, A. P. \& Kelly, D. P. (1985). Physiological characteristics of a new thermophilic obligately chemolithotrophic Thiobacillus species, Thiobacillus tepidarius. Int J Syst Bacteriol 35, 434-437.

Wood, A.P. \& Kelly, D.P. (1988). Isolation and physiological characterisation of Thiobacillus aquaesulis, sp. nov., a novel facultatively autotrophic moderate thermophile. Arch Microbiol 149, 339-343.

Received 29 March 1994; revised 26 July 1994; accepted 11 August 1994. 